\title{
Synthesis, Characterization and Antimicrobial Evaluation of Mannich Bases of 4-(Furan-2-yl-methyleneamino)-3-(2-hydroxyphenyl)-1H- 1,2,4-triazole-5-thione
}

\author{
Prem Shankar Deo ${ }^{1}$, Rhambus Rawat ${ }^{1}$, Bhushan Shakya ${ }^{* 1}$ \\ ${ }^{1}$ Department of Chemistry, Amrit Science Campus, Tribhuvan University, Kathmandu, Nepal \\ *Corresponding E-mail: bhusansakya@gmail.com
}

(Received: September 30, 2020; Revised: January 3, 2021; \& Accepted:January 3, 2021)

\begin{abstract}
Triazole nucleus has drawn much attention since the last decade because of its various potent biological activities. The pharmacological application of triazoles has been widely recognized and well documented. Schiff and Mannich bases are both considered as bioactive compounds, however, there are not much of documentation about the Mannich bases as their study has begun lately. The main aim of this study was to synthesize new Mannich bases from Schiff base bearing 1,2,4-triazole nucleus to access their antimicrobial activities. The newly synthesized compounds 1,2,4-triazole-5-thione, Schiff base (4) and Mannich bases (5a \& $5 b)$ were characterized by spectral techniques like UV, FT-IR, and NMR. Mannich bases were tested against various bacterial ( $\mathrm{gm}+\mathrm{ve}$ and $\mathrm{gm}-\mathrm{ve}$ ) as well as fungal strains. The synthesized Mannich bases showed good to moderate activities against the tested bacterial and fungal strains.
\end{abstract}

Keywords: 1,2,4-triazole-5-thione, Schiff base, Mannich base, antibacterial activity, antifungal activity

\section{Introduction}

Life on Earth relies exquisitely on heterocyclic compounds that play key roles in the biochemical reactions involved in fundamental activities such as metabolism, energy delivery, the replication of genetic material, nerve impulse transmission, etc. With their tunable properties available from the variety of structure, heterocyclic compounds allow for the design of new synthetic compounds for specific purposes like drugs, pesticides [1], detergents [2], dyes [3] polymers [4], and electronics [5]. The nitrogen-containing heterocyclic compounds have been utilized by many researchers because of their various potent biological activities, low toxicity and efficient selectivity [6]. One example of such nitrogen-containing heterocyclic compounds is Triazole containing a five-membered di-unsaturated ring structure composed of three nitrogen atoms and two carbon atoms at non-adjacent positions.

Triazoles exist as two isomers-1,2,3-triazoles and 1,2,4-triazoles [7]. The two tautomeric form of the 1,2,4-triazoles $1 H$ - and $4 H$-1,2,4-triazoles are characterized by the position of hydrogen. In the substituted 1,2,4-triazoles, 3-mercapto-1,2,4triazoles, the labile hydrogen may be attached either to the nitrogen or the sulphur atom and hence exist in two tautomeric forms - thione and thiol (Fig. 1) [8].

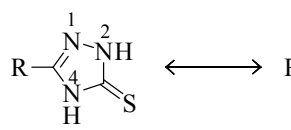

(a)

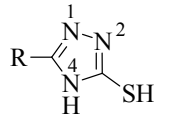

(b)
Figure 1: Thione (a) and Thiol (b) tautomers of substituted 3-mercapto 1,2,4-triazole

1, 2, 4- triazoles occupy a distinctive place in the field of medicinal and pharmaceutical chemistry [9], as well as in industry [10]. A large number of compounds containing 1,2,4-triazole nucleus as an important structural fragment have been reported to possess a wide range of biological activities such as antifungal [9], antibacterial [12-13], anticonvulsant [14], anti-tubercular [15], anti-inflammatory [9], anticancer [16-18], antioxidant [19] activities. Various drugs with 1,2,4-triazole ring have been introduced, for example, Rivabarin (antiviral agent) [20], Rizaptriptan (antimigraine agent) [21], Fluconazole, Itraconazole, (antimycotic agent) [22], Triazolam, Alprazolam, Estazolam (anticonvulsant drug) [2324], Letrozole, Anastrozole, Vorozole (aromatase inhibitors) [25-26]. 
The properties and activity of a target compound such as Schiff base [14], Mannich base [27], thiourea [28], triazolothiadiazole [29] etc. can be changed simply by incorporating various substituents to the triazole ring on a different position. Mannich bases are the $\beta$-aminoketone that are generally obtained from Mannich reaction. The great synthetic relevance of the Mannich reaction is such that two different chemical moieties could be linked together in one step by means of methylene Bridge [30].

The study of Mannich bases has increased significantly because of their ability to show biological activities as antitubercular [31-32], antimalarial [33], vasorelaxing [34], anticancer [16, 35], anti-inflammatory [36], antifilarial [37], antibacterial [38], antifungal [38], anticonvulsant [39], anthelmintic [40], analgesic [41], anti-HIV [32], antipsychotic [42], antiviral [43] activities and so forth. Besides the biological activities, Mannich bases find applications in a variety of ways including their use as fuel additives [44], resins [45], polymers [46], surfactants [47], as plant growth regulators [48-49]. In the present study, we synthesized Mannich bases following Mannich reaction by combining chemically different amines (diphenylamine and piperazine) with a pharmacologically compatible 1,2,4-triazole nucleus containing Schiff base and evaluated their antimicrobial activities.

\section{Materials and Methods \\ Starting materials}

Hydrazine hydrate was purchased form Qualigens, ethanol from Alpha Chemica, methyl salicylate, conc. sulphuric acid, furfuraldehyde, methanol, potassium hydroxide, and hydrochloric acid were purchased from Fischer scientific, carbon disulphide and diphenylamine from Merck, and piperazine from Loba Chemie.

\section{Physical measurements}

Melting points of the synthesized compounds were determined with electrothermal apparatus from Optics technology. TLC of synthesized compounds was performed on silica gel coated plates using $n$-hexane : ethyl acetate solvent system and the spots were visualized by iodine vapuors in an iodine chamber. UV-visible electronic spectra in DMSO were recorded on double beam UV-Visible spectrophotometer of Labtronics (Model LT-2802) in the region 1100-200 nm. FT-IR spectra were measured in the range of (4000-400) $\mathrm{cm}^{-1}$ using $\mathrm{KBr}$ on IR prestige-21, Shimadzu, Japan. ${ }^{1} \mathrm{H}-\mathrm{NMR}$ and ${ }^{13} \mathrm{C}$-NMR were recorded on Bruker AV III $500 \mathrm{MHz}$ NMR using DMSO as the solvent and chemical shifts are expressed in $\delta$ ppm.

\section{Synthesis and analyses}

The compounds were synthesized from the starting materials as shown in the scheme1.

\section{Synthesis of 2-hydroxybenzohydrazide (1)}

2-Hydroxybenzohydrazide (1) was prepared by refluxing a mixture of hydrazine monohydrate (4.5 $\mathrm{mL}, 0.090 \mathrm{~mol})$ and methyl salicylate $(9.129 \mathrm{~g}, 0.060$ $\mathrm{mol})$ for $6 \mathrm{~h}$ [50]. The volume of the resulting solution was reduced to half by evaporation on a hot water bath and cooled. White crystalline solid separated out was filtered, washed with cold ethanol and recrystallized with absolute ethanol and was dried in a hot air oven at 50-60 ${ }^{\circ} \mathrm{C}$. Yield - $79 \%$ (7.228 g), white solid, mp $145-147^{\circ} \mathrm{C}, \mathrm{R}_{f}=0.64$ ( $n$-hexane : ethyl acetate, 8:2).

\section{Synthesis of potassium 2-(2-hydroxybenzoyl) hydrazinecarbodithioate (2)}

To the ice-cold ethanol solution $(\sim 20 \mathrm{~mL})$ containing 2-hydroxybenzohydrazide $(4.565 \mathrm{~g}, 0.030 \mathrm{~mol})$ and potassium hydroxide $(1.683 \mathrm{~g}, 0.030 \mathrm{~mol})$, carbon disulphide (2.284 g, $0.030 \mathrm{~mol}$ ) was added dropwise

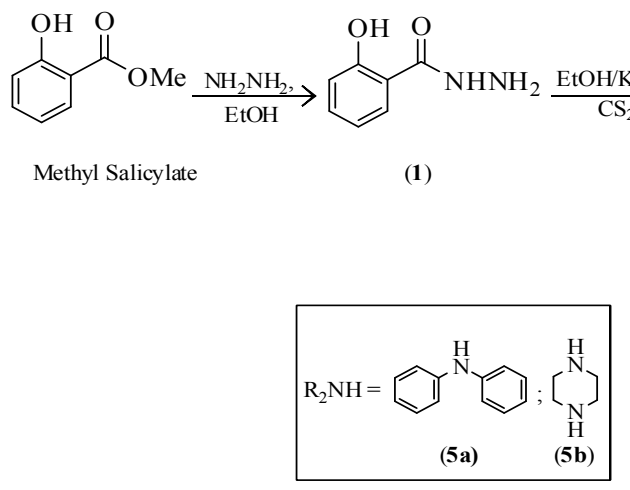<smiles>C1CCCCC1</smiles><smiles>O=C(NC(=O)c1ccccc1O)NC(=S)S</smiles>

(2)

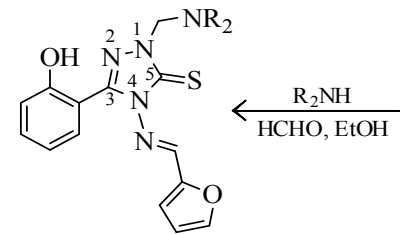

(5)
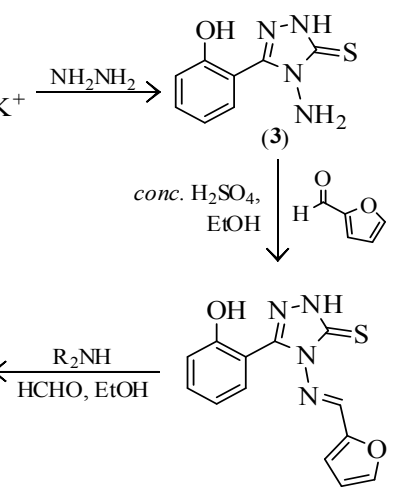

(4)

Scheme 1: Synthetic route for the synthesis of Mannich bases of 1,2,4-triazole 
with constant stirring. The solution was stirred for 21 hours at room temperature on a magnetic stirrer. Anhydrous diethyl ether $(\sim 20 \mathrm{~mL})$ was added, the precipitated solid was washed twice with anhydrous diethyl ether and dried in a desiccator [51]. Yield $62 \%$ (4.898 g), white solid, $\mathrm{mp} 240{ }^{\circ} \mathrm{C}, \mathrm{R}_{f}=0.58$ ( $n$-hexane : ethyl acetate, 8:2).

\section{Synthesis of 4-amino-2-(2-hydroxyphenyl)-1H- 1,2,4-triazole-5-thione (3)}

A suspension of potassium 2-(2-hydroxybenzoyl) hydrazinecarbodithioate $(4.680 \mathrm{~g}, 0.018 \mathrm{~mol})$ and hydrazine monohydrate $(1.5 \mathrm{~mL})$ in distilled water $(\sim 5 \mathrm{~mL})$ was refluxed for $5 \mathrm{~h}$ till the evolution of hydrogen sulphide gas was ceased. The reaction mixture was cooled, diluted with ice-cold water $(\sim 50$ $\mathrm{mL}$ ) and acidified with conc. $\mathrm{HCl}$. The solid product was separated by filtration, washed twice with cold water $(30 \mathrm{~mL})$ and recrystallized with absolute ethanol [52]. Yield: $79 \%$ (2.894 g, $0.014 \mathrm{~mol})$, off white solid, m.p. $166-169{ }^{\circ} \mathrm{C}, \mathrm{R}_{\mathrm{f}}$ : 0.35 (n-hexane :ethyl acetate, 8:2). UV- Visible spectrum $\left(\lambda_{\text {max }}\right) \mathrm{nm}=$ $302,309,331,353$. IR spectrum (selected bands) $\mathrm{cm}^{-1}$ $=3287,3186,3063,1612,1543,1296,946 .{ }^{1} \mathrm{H}-\mathrm{NMR}$ $\left(500 \mathrm{MHz}, \mathrm{DMSO}-\mathrm{d}_{6}\right) \delta \mathrm{ppm}=13.86(\mathrm{br} \mathrm{s}, 1 \mathrm{H}, \mathrm{NH})$, $10.36(\mathrm{~s}, 1 \mathrm{H}, \mathrm{OH}), 7.43-7.31(\mathrm{~m}, 2 \mathrm{H}, \mathrm{Ar}-\mathrm{H}), 7.00$ (d, $\mathrm{J}=8.20 \mathrm{~Hz}, 1 \mathrm{H}, \mathrm{Ar}-\mathrm{H}), 6.93(\mathrm{t}, \mathrm{J}=7.57 \mathrm{~Hz}, 1 \mathrm{H}, \mathrm{Ar}-$ $\mathrm{H}), 5.62$ (br s, $\left.2 \mathrm{H}, \mathrm{NH}_{2}\right) \cdot{ }^{13} \mathrm{C}-\mathrm{NMR}\left(125 \mathrm{MHz}, \mathrm{d}_{6}\right) \delta$ ppm $=166.54$ (Triazole-C5), 156.53 (Ar-C), 149.62 (Triazole-C3), 132.6 (Ar-C), 131.32 (Ar-C), 119.5 (Ar-C), 116.67 (Ar-C), 113.52 (Ar-C).

Synthesis of Schiff's base 4-(furan-2-ylmethyleneamino)-3-(2-hydroxyphenyl)-1H-1,2,4triazole-5-thione (4)

A hot ethanolic solution $(\sim 5 \mathrm{~mL})$ of furfuraldehyde $(1.922 \mathrm{~g}, 0.020 \mathrm{~mol})$ and triazole thione $(4.165 \mathrm{~g}$, $0.020 \mathrm{~mol}$ ) was refluxed for $\sim 5 \mathrm{~h}$ in presence of 5 drops of conc. sulphuric acid. The solid mass obtained on cooling was filtered under suction, washed with cold ethanol and recrystallized with hot ethanol [53]. Yield: $65 \%$ (3.626 g, $0.013 \mathrm{~mol})$, greyish black crystalline solid, m.p. $161-163{ }^{\circ} \mathrm{C}, \mathrm{R}_{\mathrm{f}}: 0.74$ (n-hexane: ethyl acetate, 8:2). UV- Visible spectrum $\left(\lambda_{\max }\right) \mathrm{nm}=$ 302, 309, 331, 353. 394. IR spectrum (selected bands) $\mathrm{cm}^{-1}=3356,3225,3093,2931,1614,1540,1236$, 948. ${ }^{1} \mathrm{H}-\mathrm{NMR}\left(500 \mathrm{MHz}, \mathrm{DMSO}-\mathrm{d}_{6}\right) \delta \mathrm{ppm}=14.09$ (br s, $1 \mathrm{H}$, triazole $\mathrm{N} \underline{\mathrm{H}}), 10.06(\mathrm{~s}, 1 \mathrm{H}, \mathrm{OH}), 9.42$ (s, $1 \mathrm{H}, \mathrm{N}=\mathrm{C} \underline{\mathrm{H}}$ ), 7.98 (br s, 1H, Furan-H), 7.39 (br s, 1H, Ar-H), 7.37 (br s, 1H, Ar-H), 7.31 (d, $J=3.15 \mathrm{~Hz}$, 1H, Ar-H), 6.93-6.90 (m, 2H, Ar-H \& Furan-H), 6.73 (dd, $J=1.89,3.78 \mathrm{~Hz}, 1 \mathrm{H}$, Furan-H), ${ }^{13} \mathrm{C}-\mathrm{NMR}(125$
$\left.\mathrm{MHz}, \mathrm{d}_{6}\right) \delta \mathrm{ppm}=162.14(\mathrm{~N}=\underline{\mathrm{CH}}), 156.66($ Triazole C5), 154.43 (Ar-C), 148.83 (Triazole C3), 148.35 (Furan-C), 147.67 (Furan-C), 132.82 (Ar-C), 131.61 (Ar-C), 120.93 (Ar-C), 119.37 (Furan-C), 116.46 (ArC), 113.42 (Ar-C), 113.39 (Furan-C).

\section{Synthesis of Mannich's base 1-\{(diphenylamino) methyl\}-4-(furan-2-ylmethyleneamino)-3-(2- hydroxyphenyl)-1H-1,2,4-triazole-5-thione (5a)} A mixture $40 \%$ formaldehyde $(0.3 \mathrm{~mL}, 0.01 \mathrm{~mol})$, hot ethanolic solution of Schiff's base (1.432 g, 0.005 $\mathrm{mol})$ and diphenylamine $(0.846 \mathrm{~g}, 0.005 \mathrm{~mol})$ was refluxed for $3 \mathrm{~h}$. Excess amount of distilled water was added and the reaction mixture was left overnight. The precipitate was filtered under suction, washed with cold ethanol and recrystallized by absolute ethanol [53]. Yield: 66\% (1.540 g, $0.033 \mathrm{~mol})$, brownish black crystalline solid, m.p. $109-110{ }^{\circ} \mathrm{C}$, $\mathrm{R}_{\mathrm{f}}: 0.72$ ( $n$-hexane : ethyl acetate, 8:2). UV- Visible spectrum $\left(\lambda_{\max }\right) \mathrm{nm}=302,309,339,353,393$. IR spectrum (selected bands) $\mathrm{cm}^{-1}=3217,2932,1605$, 1497, 1234, 933. ${ }^{1} \mathrm{H}-\mathrm{NMR}$ (500 MHz, DMSO- $\mathrm{d}_{6}$ ) $\delta$ $\mathrm{ppm}=10.93(\mathrm{~s}, 1 \mathrm{H}, \mathrm{O} \underline{\mathrm{H}}), 9.32(\mathrm{~s}, 1 \mathrm{H}, \mathrm{N}=\mathrm{C} \underline{\mathrm{H}}), 8.14$ (br s, 1H. Ar-H), 8.00 (br s, 1H, Furan-H), 7.96-7.94 $(\mathrm{dd}, J=8.20 \times(2), 1 \mathrm{H}, \mathrm{Ar}-\mathrm{H}), 7.51-7.44(\mathrm{~m}, 1 \mathrm{H}, \mathrm{Ar}-$ $\mathrm{H})$, 7.37-7.29 (m,4H, Diphenylamine-H \& Furan-H), 7.27-7.20 (m, 4H, Diphenylamine-H \& Furan-H), $7.08(\mathrm{~d}, J=8.20,1 \mathrm{H}, \mathrm{Ar}-\mathrm{H}), 6.82(\mathrm{dd}, J=5.7 \mathrm{~Hz}, 1 \mathrm{H}$, Furan $-\mathrm{H}), 6.16\left(\mathrm{~s}, 2 \mathrm{H}, \mathrm{N}-\underline{\mathrm{H}}_{2}-\mathrm{N}\right) \cdot{ }^{13} \mathrm{C}-\mathrm{NMR}(125$ $\left.\mathrm{MHz}, \mathrm{d}_{6}\right) \delta \mathrm{ppm}=166.30($ Triazole C5), $159.02($ ArC), 148.57 (Triazole C3), 147.54 (Furan-C), 146.65 (2C, Diphenhylamine-C), 143.90 (2C, Furan-C), $134.55(\mathrm{~N}=\underline{\mathrm{CH}}), 129.61$ (4C, Diphenyl-C), 121.93 (2C, Diphenhylamine-C), 120.11 (Ar-C), 119.72 (Furan-C), 117.74 (4C, Diphenhylamine-C), 117.19 (Ar-H), 115.43 (2C, Furan-H), 113.44 (Ar-H), 88.61 $\left(\mathrm{N}-\underline{C H}_{2}-\mathrm{N}\right)$.

\section{Synthesis of Mannich's base 4-(furan-2- ylmethylemeamino)-3-(2-hydroxyphenyl)-1- (piperazin-1-ylmethyl)-1H-1,2,4-triazole-5- thione (5b)}

A mixture $40 \%$ formaldehyde $(0.3 \mathrm{~mL}, 0.01 \mathrm{~mol})$, hot ethanolic solution of Schiff's base (1.432 g, 0.005 $\mathrm{mol})$ and piperazine $(0.431 \mathrm{~g}, 0.005 \mathrm{~mol})$ was refluxed for $3 \mathrm{~h}$. Excess amount of distilled water was added and the reaction mixture was left overnight. The precipitate was filtered under suction, washed with cold ethanol and recrystallized by absolute ethanol. Yield: 78\% (1.501 g, $0.004 \mathrm{~mol})$, brown solid, m.p. 140-142 ${ }^{\circ} \mathrm{C}, \mathrm{R}_{\mathrm{f}}: 0.89$ (n-hexane : ethyl acetate, 8:2). UV- Visible spectrum $\left(\lambda_{\max }\right) \mathrm{nm}=302,309,339$, 
354, 405. IR spectrum (selected bands) $\mathrm{cm}^{-1}=3240$, 2939, 2831, 1705, 1551, 1304, 934. ${ }^{1} \mathrm{H}-\mathrm{NMR}(500$ $\left.\mathrm{MHz}, \mathrm{DMSO}-\mathrm{d}_{6}\right) \delta \mathrm{ppm}=10.13(\mathrm{~s}, 1 \mathrm{H}, \mathrm{OH}), 9.39$ $(\mathrm{s}, 1 \mathrm{H}, \mathrm{N}=\mathrm{C} \underline{\mathrm{H}}), 8.12$ (br s, $1 \mathrm{H}, \mathrm{Ar}-\mathrm{H}), 8.00$ (br s, $1 \mathrm{H}$, Furan-H), 7.93 (dd, $J=8.20 \mathrm{~Hz} \times(2), 1 \mathrm{H}, \mathrm{Ar}-\mathrm{H})$, 7.51-7.42 (m, 1H, Ar-H), 7.13 (d, $J=8.20,1 \mathrm{H}$, Ar-H), 5.13 (s, $2 \mathrm{H}, \mathrm{N}-\mathrm{CH}_{2}-\mathrm{N}$ ), 3.87 (br s, 4H, Piperazine-C), 3.82 (br s, 4H, Piperazine-C), 2.79 (br s, 1H, N느Piperazine $){ }^{13} \mathrm{C}-\mathrm{NMR}\left(125 \mathrm{MHz}, \mathrm{d}_{6}\right) \delta \mathrm{ppm}=166.13$ (Triazole C5), 159.05 (Ar-C), 148.57 (Triazole C3), 147.22 (Furan-C), 145.55 (Furan-C), $134.55(\mathrm{~N}=\underline{\mathrm{CH}})$, 129.27 (Ar-C), 125.60 (Ar-C), 121.58 (Ar-C), 119.63 (Furan-C), 117.73 (Ar-C), 113.15 (Furan-C), 77.33 (N-ㅌH2-N), 53.90 (2C, Piperzine-C), 44.22 (2C, Piperzine-C).

\section{Antimicrobial (antibacterial and antifungal) screening}

The antimicrobial activities of the newly synthesized Mannich bases were screened against different gram-positive bacterial strains - Bacillus subtilis, Enterococcus faecalis, Staphylococcus aureus, and Staphylococcus epidermis; gram-negative bacterial strains - Escherichia coli, Klebsiella pneumonia, Proteus vulgaris, Pseudomonas aeruginosa, Shigella dysenteriae, and fungal strains - Candida albicans, Saccharomyces cerevisiae according to agar well diffusion methods as described by Perez et al, [54]. The overnight culture of bacterial and fungal strains from nutrient agar and potato dextrose agar respectively was adjusted to $0.5 \mathrm{Mc}$ Farland standards over the appropriate medium Muller-Hinton Agar (MHA) for bacteria and Muller-Hinton Agar with Glucose and Methylene Blue (MHA, GMB) for fungi by using a sterile swab. On each agar plate wells of 6 $\mathrm{mm}$ diameter suitably separated were loaded with 50 $\mu \mathrm{L}$ of the test solution of the samples and solvent as a negative control. Chloramphenicol $\left(60 \mathrm{mcg} \cdot \mathrm{mL}^{-1}\right)$ and Clotrimazole (200 mcg. $\left.\mathrm{mL}^{-1}\right)$ were used as reference antibacterial and antifungal respectively. The inoculated plates were kept at a suitable temperature $\left(35 \pm 2{ }^{\circ} \mathrm{C}\right.$ for bacteria and $25 \pm 2{ }^{\circ} \mathrm{C}$ for fungi). After proper incubation (18-24 h for bacteria, 24-48 h for fungi) the plates were examined for zone of inhibition (ZOI) around the well which is suggested by clear area with no growth of organisms.

\section{Results and Discussion}

\section{Chemistry}

Mannich base $5 \mathrm{a} \& 5 \mathrm{~b}$ were synthesized from the Schiff base containing 1,2,4-triazole-5-thione nucleus according to the scheme 1 . Methyl salicylate was refluxed with hydrazine hydrate and ethanol to yield acid hydrazide (1). Treatment of (1) with alcoholic potassium hydroxide and carbon disulphide resulted in the formation of dithiocarbazinate (2). The ring closure of compound (2) in presence of excess hydrazine hydrate in ethanol gave 4-amino2-(2-hydroxyphenyl)-1H-1,2,4-triazole-5-thione (3). Condensation of 1,2,4-triazole (3) with furfuraldehyde and refluxed with ethanol along with conc. $\mathrm{H}_{2} \mathrm{SO}_{4}$ as catalyst gave 4-(furan-2-yl-methyleneamino)-3(2-hydroxyphenyl)-1H-1,2,4-triazole-5-thione (4). Mannich bases were synthesized finally by refluxing formaldehyde, ethanolic solution of Schiff base (4) and diphenylamine to form (5a), whereas $(5 b)$ is formed when piperazine is used instead of diphenylamine.

\section{Spectroscopic studies}

The structure of the 1,2,4-triazole-5-thione, Schiff base and Mannich bases were confirmed by UV, FTIR, ${ }^{1} \mathrm{H}-\mathrm{NMR}$ and ${ }^{13} \mathrm{C}-\mathrm{NMR}$ spectral techniques.

\section{$U V$-Visible spectral analysis}

The UV-visible electronic spectra of the compounds were studied in DMSO. All the synthesized compounds showed the absorbance at 302 and 309 $\mathrm{nm}$ which corresponds to the aromatic $\mathrm{C}=\mathrm{C}$ and azomethine $\mathrm{C}=\mathrm{N}\left(\pi \rightarrow \pi^{*}\right)$ of triazole ring. Compound (3) also exhibited absorptions at $331 \mathrm{~nm}$ due to $\left(n \rightarrow \pi^{*}\right)$ transitions associated with the nonbonding electron pair of the nitrogen atom of triazole $\mathrm{C}=\mathrm{N}$ and sulphur atom of $\mathrm{C}=\mathrm{S}$. The absorption at 353 $\mathrm{nm}$ is attributable to $\left(n \rightarrow \pi^{*}\right)$ transitions associated with o-hydroxy group. Compound (4) also showed three other bands at $339 \mathrm{~nm}, 353 \mathrm{~nm}$ and $394 \mathrm{~nm}$ associated $\left(n \rightarrow \pi^{*}\right) \mathrm{C}=\mathrm{N}$ and $\mathrm{C}=\mathrm{S},\left(n \rightarrow \pi^{*}\right)$ transitions of $o$-hydroxy group and $\left(n \rightarrow \pi^{*}\right)$ transitions of azomethine group $\mathrm{C}=\mathrm{N}$ respectively [55]. Compound (5a) \& (5b) exhibited three other electronic transitions - one at $339 \mathrm{~nm}$ because of the $\left(n \rightarrow \pi^{*}\right)$ electronic transitions of triazole $\mathrm{C}=\mathrm{N}$ and sulphur atom of $\mathrm{C}=\mathrm{S}$, another at $353 \& 354 \mathrm{~nm}$ (Mannich base 5a \& 5b respectively) associated with $\left(n \rightarrow \pi^{*}\right)$ transitions of o-hydroxy group, and the next band at 393 and $405 \mathrm{~nm}$ respectively due to $\left(n \rightarrow \pi^{*}\right)$ transitions of azomethine group $\mathrm{C}=\mathrm{N}$.

\section{FT-IR spectral analysis}

The formation of triazole (3) is confirmed by the presence of a medium band at $1296 \mathrm{~cm}^{-1}$ and strong band at $946 \mathrm{~cm}^{-1}$ corresponding to $\mathrm{N}-\mathrm{C}=\mathrm{S}$ thioamide II and $\mathrm{C}=\mathrm{S}$ thioamide IV. Moreover, no absorption bands were detected about $1651-1707 \mathrm{~cm}^{-1}$ indicating 
the absence of $\mathrm{C}=\mathrm{O}$ group of the compound which is the evidence for the conversion of dithiocarbazinate to triazoles [56]. The absence of band at $1700 \mathrm{~cm}^{-1}$ clearly indicates the amino condensation and hence the formation of Schiff bases [53]. The absence of medium intensity bands in the region of 3500-3200 $\mathrm{cm}^{-1}$ attributable to $-\mathrm{NH}_{2}$ protons demonstrates the formation of Schiff bases [57]. Further, absence of an absorption band in the region of $2300-2600 \mathrm{~cm}^{-1}$ region cited for the-SH group clearly states that, in the solid-state, the compound exists predominantly in the thionic form [58-59]. The formation of Mannich bases (5a) \& (5b) is supported by the presence of medium absorption band at $1234 \mathrm{~cm}^{-1}$ and weak absorption band at $1304 \mathrm{~cm}^{-1}$ respectively due to $\mathrm{N}-\mathrm{C}=\mathrm{S}$ group and also the absence of absorption band at $2550 \mathrm{~cm}^{-1}$ due to S-H structure, hence, supporting the formation of N- Mannich bases but not S- Mannich bases [53].

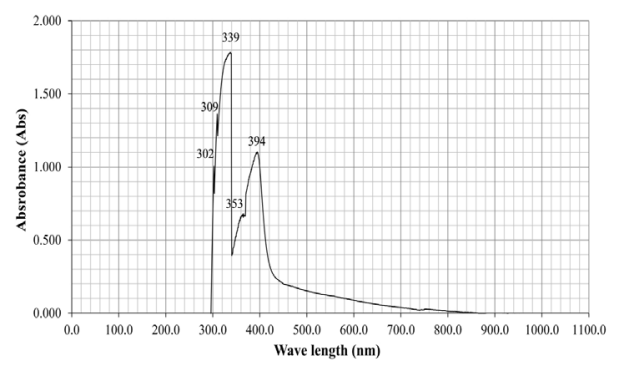

Figure 2: UV-Visible spectrum of compound 4

\section{${ }^{1} \mathrm{H}$-NMR spectral analysis}

In ${ }^{1} \mathrm{H}-\mathrm{NMR}$ spectrum of compound (3), the broad singlet at $13.86 \mathrm{ppm}$ is attributed to the hydrogen attached to the nitrogen which suggests the formation of thione based triazole [60] which is equally supported by the absence of IR absorption band at $2600 \mathrm{~cm}^{-1}$ due to thiol group. The ${ }^{1} \mathrm{H}-\mathrm{NMR}$ spectrum of Schiff base showed a singlet at 9.42 due to presence of $-\mathrm{N}=\mathrm{CH}$ group and absence of signals approximately at 5.76 ppm $\left(\mathrm{NH}_{2}\right)$ in the molecule confirming the formation of Schiff bases. The absence of exchangeable -SH signals c.a. $4.0 \mathrm{ppm}$ indicated the predominance of the thione tautomer in DMSO- $\mathrm{d}_{6}[61]$. The singlets found at $6.16 \mathrm{ppm}$ and $5.13 \mathrm{ppm}$ due to $\mathrm{N}-\mathrm{CH}_{2}-\mathrm{N}$ group confirms the formation of Mannich bases (5a $\& 5 b)$ from Schiff base. Moreover, the absence of a peak at $11.5 \mathrm{ppm}$ clearly suggests the absence of thiol group in the structure instead thione based Mannich base is formed [53].

\section{${ }^{13}$ C-NMR spectral analysis}

The typical carbon resonance at $\delta 162.57-167.67 \mathrm{ppm}$ was indicative of triazole $\mathrm{C} 5$, i.e., $\mathrm{C}=\mathrm{S}$ group [62].

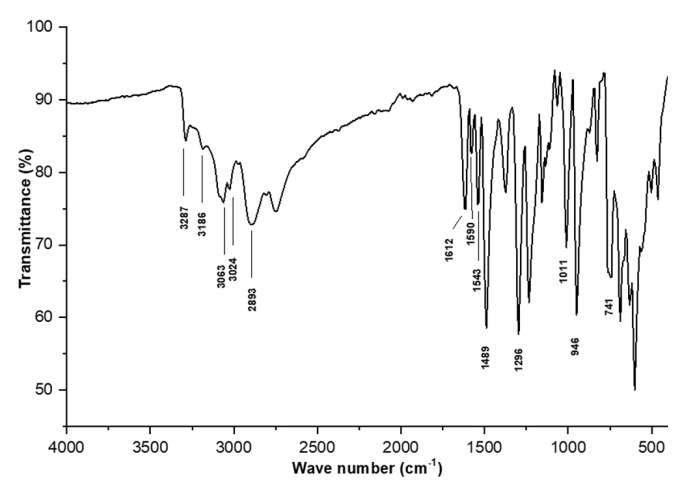

Figure 3: IR spectrum of compound 3

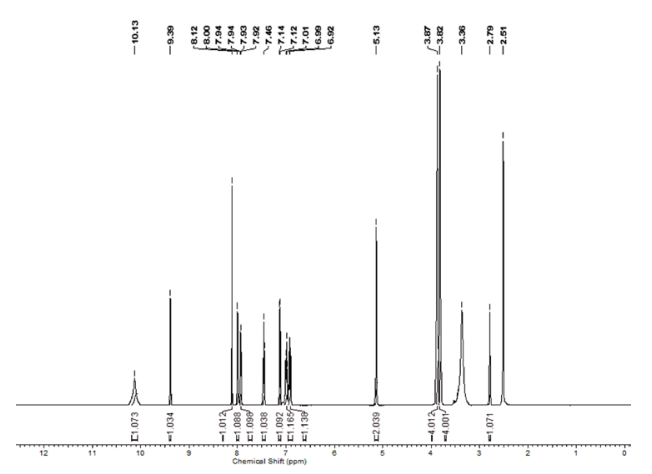

Figure 4: ${ }^{1} H$ NMR spectrum of compound $5 b$

The compounds $3,4,5 \mathrm{a} \& 5 \mathrm{~b}$ consists of a peak at $166.54,162.14,166.30$ and 166.13 ppm respectively. The signal of $\mathrm{C}=\mathrm{N}$ is observed at $149.62,148.83$, 148.57 and $148.57 \mathrm{ppm}$ for compounds 3,4 , 5a \& $5 \mathrm{~b}$ respectively. The peak found at $156.66 \mathrm{ppm}$ due to the azomethine carbon confirms the formation of Schiff base [63]. In compound 5a, the aromatic carbons of diphenyl group were found in the region of 146.65-117.74 ppm whereas the piperazine carbon (5b) was found in the region of $53.90 \& 44.22 \mathrm{ppm}$ [62]. The formation of Mannich bases (5a \& 5b) were confirmed by the presence of peak at $88.61 \mathrm{ppm}$ and $77.33 \mathrm{ppm}$ respectively.

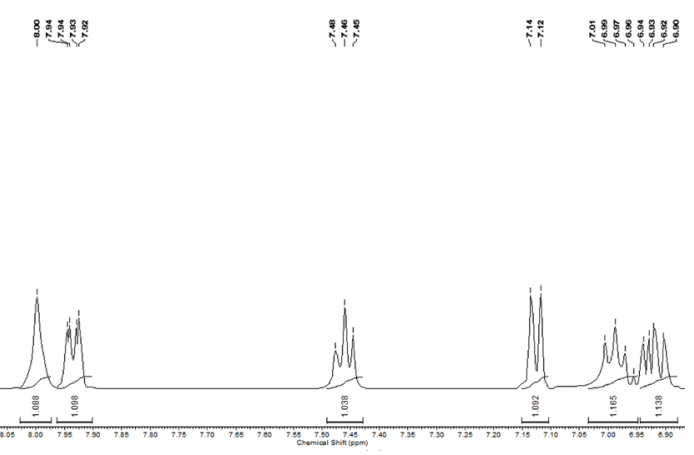

Figure 5: Expanded ${ }^{1} H$ NMR spectrum of compound $5 b$ 


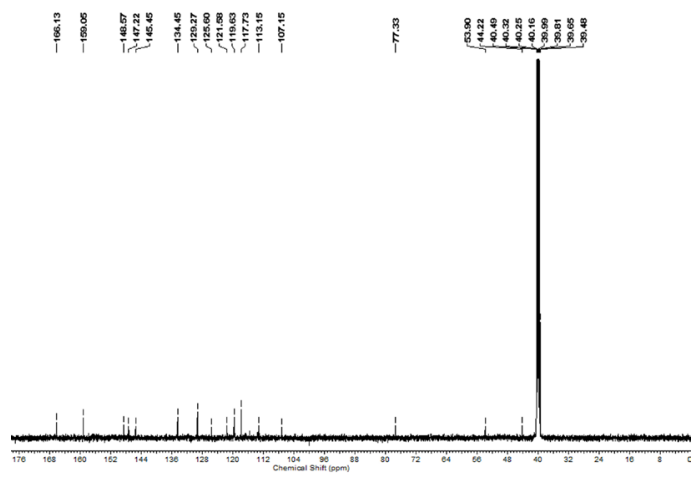

Figure 6: ${ }^{13} \mathrm{C}$ NMR spectrum of compound $5 b$

\section{Antimicrobial screening}

The antimicrobial screening revealed that the compounds showed moderate activity against bacterial strains and good activity against fungi. Compound 5a with diphenylamine appeared more active against gram -ve bacteria than gram +ve bacteria, while compound $5 \mathrm{~b}$ with piperazine was found to be more effective against gram +ve bacteria than gram -ve.
Compound $5 \mathrm{a}$ showed better activity against gramnegative bacterial strain of Proteus vulgaris than any other bacterial strain whereas $5 b$ showed the greatest activity against gram-positive bacterial strain Staphylococcus aureus against which 5a was ineffective. Compound 5a exhibited remarkable activity against the bacterial strains $P$. vulgaris and $P$. aeruginosa towards which the standard antibacterial chloramphenicol showed no activity. Likewise, compound $5 \mathrm{~b}$ was also found to be effective against $P$. vulgaris. Both Mannich bases were ineffective against $B$. subtilis, and $S$. epidermidis.

Both $5 \mathrm{a}$ and $5 \mathrm{~b}$ exhibited remarkable activity against the fungal strains $C$. albicans and $S$. crevisiae comparable to that of the standard drug clotrimazole. The piperizinyl derivative $5 \mathrm{~b}$ exhibited more potent antifungal activity than the diphenylamine derivative $5 \mathrm{a}$.

Compound $5 \mathrm{~b}$ showed better antifungal activity than compound 5 a for both fungal strains.

Table 1: Inhibition zones showing antimicrobial activities of Mannich bases and reference antibiotic

\begin{tabular}{|c|c|c|c|c|}
\hline \multirow{2}{*}{ Microbial Strain } & \multicolumn{3}{|c|}{ Diameter of Zone of Inhibition (mm) } & \multirow[b]{2}{*}{$\begin{array}{c}\text { Clotrimazol } \\
\text { Conc }^{n}\left(200 \text { meg.mL }^{-1}\right)\end{array}$} \\
\hline & $\begin{array}{l}\text { Compound } \\
\text { (5a) }\end{array}$ & $\begin{array}{c}\text { Compound } \\
(5 b)\end{array}$ & $\begin{array}{l}\text { Chloramphenicol } \\
\text { Conc }^{n}\left(60 \text { mcg.mL }^{-1}\right)\end{array}$ & \\
\hline Bacillus subtilis ${ }^{a}$ & - & - & 26.6 & $\mathrm{NT}$ \\
\hline Enterococcus faecalis ${ }^{a}$ & 7.0 & 8.0 & 20.9 & NT \\
\hline Staphylococcus aureus ${ }^{a}$ & - & 14.5 & 28.4 & NT \\
\hline Staphylococcus epidermidis ${ }^{a}$ & - & - & 31.7 & NT \\
\hline Escherichia colib & 7.8 & 7.3 & 20.9 & NT \\
\hline Klebsiella pneumoniae $^{b}$ & 7.7 & - & 12.3 & NT \\
\hline Proteus vulgaris ${ }^{b}$ & 9.7 & 12.2 & - & NT \\
\hline Pseudomonas aeruginosa ${ }^{b}$ & 8.5 & - & - & NT \\
\hline Shigella dysenteriae $e^{b}$ & 7.0 & - & 29.0 & NT \\
\hline Candida albicans $f^{f}$ & 18.1 & 21.7 & NT & 32.3 \\
\hline Saccharomyces cerevisiaef & 12.5 & 19.4 & NT & 24.4 \\
\hline
\end{tabular}

'-' No activity; ${ }^{a}$ Gram positive bacteria; ${ }^{b}$ Gram negative bacteria; ${ }^{f}$ fungi, NT $=$ not tested

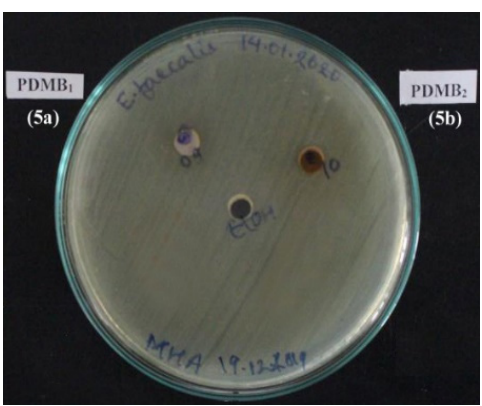

(a)

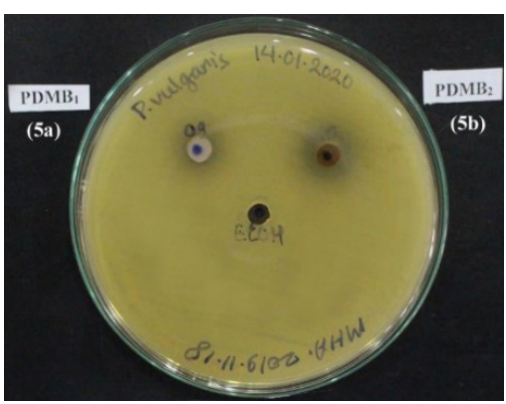

(b)

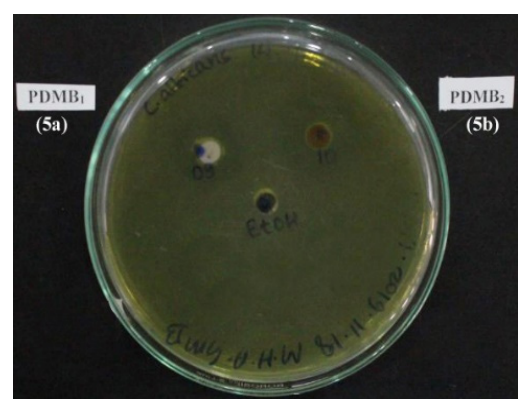

(c)

Figure 7: Antimicrobial activity of Mannich bases against (a) Enterococcus faecalis (Gram +ve bacteria) (b) Proteus vulgaris (Gram-ve bacteria) and (c) Candida albicans (Fungi) 


\section{Conclusion}

A new Schiff base 4-(furan-2-yl-methyleneamino)-3(2-hydroxyphenyl)-1H-1,2,4-triazole-5-thione and two new Mannich bases viz. 1-\{(diphenylamino)methyl $\}-$ 4-(furan-2-ylmethyleneamino)-3-(2-hydroxyphenyl)1H-1,2,4-triazole-5-thione and 4-(furan-2ylmethylemeamino )-3-(2-hydroxyphenyl)-1 (piperazin-1-ylmethyl)-1H-1,2,4-triazole-5-thione were prepared. These synthesized compounds were characterized by spectroscopic techniques (UV, FTIR, ${ }^{1} \mathrm{H}-\mathrm{NMR}$ and $\left.{ }^{13} \mathrm{C}-\mathrm{NMR}\right)$. The Mannich 5a with diphenylamine exhibited broad-spectrum against gram-negative bacterial strain than compound $5 \mathrm{~b}$ with piperazine. However, compound $5 \mathrm{~b}$ was found to be more potent in bacterial as well as fungal inhibition than 5a. 1,2,4-Triazole Mannich bases exhibit more promising antifungal activity than antibacterial activity.

\section{Acknowledgments}

The authors would like to acknowledge the University Grants Commission of Government of Nepal for the financial support through the Faculty Research Grant provided to B. Shakya (FRG2075/76-S\&T-3); Department of Plant Resources, Thapathali, Kathmandu, Nepal for the FT-IR spectra and antimicrobial screening; SAIF, IIT Madras, Chennai, India for NMR spectra; and Hari Bhakta Oli (Department of Chemistry, Amrit Campus) for the UV-Visible data acquisition.

\section{References}

1. S. Cerezo-Galvez, T. Bretschneider, C. Grondal, R. Fischer, M. Fuesslein, P. Reinisch, M. Gueclue, K. Ilg, P. Loesel and O. Malsam, Heterocyclic compounds as pesticides, U.S. Patent US9920059-B2, March 20, 2018.

2. P. Gourdon, J. L. Andersen, K. L. Hein, M. Bublitz, B. P. Pedersen, X-Y. Liu, L. Yatime, M. Nyblom, T. T. Nielsen, C. Olesen, J. V. Møller, P. Nissen, and J. P. Morth, HiLiDe-Systematic approach to membrane protein crystallization in lipid and detergent. Crystal Growth and Design, 2011, 11(6), 2098-2106. (DOI: 10.1021/cg101360d).

3. P. Yang, P. A. Martos, and B. Barrett, Symposium introduction: 51st North American Chemical Residue Workshop, Journal of Agriculture and Food Chemistry, 2015, 63(21), 5099.

(DOI: 10.1021/acs.jafc.5b00159).

4. K. Fuji, S. Tampa, K. Shono, A. Sugie, and A. Mori, Murahashi, coupling polymerization: Nickel(II)- $N$-heterocyclic carbene complexcatalyzed polycondensation of organolithium species of (hetero)arenes. Journal of American Chemical Society, 2013, 135(33), 12208-12211. (DOI:10.1021/ja406374t).

5. H. Nomura, S. Kawakami, N. Ohsawa, S. Seo, Triazole derivative, and light-emitting element, light emitting device, and electronic device with the use of triazole derivative, U. S. Patent US20160268515 A1, September 15, 2016.

6. J. Zhang and G. Xiao, Study progress in nitrogenous heterocyclic compounds, Shiyou Huagong/Petrochemical Technology. 2011, 40, 579-584.

7. K. T. Potts, The chemistry of 1,2,4-triazoles, Chemical Reviews, 1961, 61(2), 87-127. (DOI: 10.1021/cr60210a001).

8. R. M. Balabin, Tautomeric equilibrium and hydrogen shifts in tetrazole and triazoles: Focalpoint analysis and ab-initio limit, Journal of Chemical Physics, 2009, 131(154307), 1- 8. (DOI: 10.1063/1.3249968).

9. S. Maddila, R. Pagadala, and S. B. Jonnalagadda, 1,2,4-Triazoles: A review of synthetic approaches and the biological activity, Letters in Organic Chemistry, 2013, 10(10), 693-714. (DOI: 10.217 4/157017861010131126115448).

10. M. M. Antonijevic and M. B. Petrovic, Copper corrosion inhibitors. A review. International Journal of Electrochemical Science, 2008, 3(1), $1-28$.

11. K. P. Kapri, S. B. Singar and B. Shakya, Synthesis of Schiff bases of 4-amino-5-(2-hydroxyphenyl)$4 H$-1,2,4-triazole-3-thiol as potent antimicrobial agents, Amrit Research Journal, 2020, 1(1) 29-36. (DOI: 10.3126/arj.v1i1.32450).

12.P. Zoumpoulakis, C. Camoutsis, G. Pairas, M. Sokovic, J. Glamoclija, C. Potamitis and A. Pitsas, Synthesis of novel sulfonamide-1,2,4-triazoles, 1,3,4-thiadiazoles and 1,3,4-oxadiazoles, as potential antibacterial and antifungal agents, Biological evaluation and conformational analysis studies. Bioorganic \& Medicinal Chemistry, 2012, 20(4), 1569-1583. (DOI: 10.1016/j. bmc.2011.12.031).

13. I. Küçükgüzel, S. G. Küçükgüzel, S. Rollas, G. Otuk-Sanis, O. Ozdemir, I. Bayrak, T. Altug, and J. P. Stables, Synthesis of some 3-(aryl/alkylthio)4-alkyl/aryl-5-(4-aminophenyl)-4H-1,2,4-triazole derivatives and their anticonvusltant activity. $I l$ Farmaco, 2004, 5(11), 893-901. (DOI: 10.1016/j. farmac.2004.07.005).

14. I. Küçükgüzel, S. G. Küçükgüzel, S. Rollas, and M. Kiraz, M. (2001). Some 3-thioxo/alkylthio1,2,4triazoles with a substituted thiourea moiety as possible antimycobacterials. Bioorganic and 
Medicinal Chemistry Letters, 2001, 11(13), 17031707. (DOI: 10.1016/S0960-894X(01)00283-9).

15.R. Paprocka, M. Wiese, A. Eljaszewicz, A. Helmin-Basa, A. Gzell, B. M. Banachiewicz, and J. Michalkiewicz. 2015. Synthesis and antiinflammatory activity of new 1,2,4-triazole derivatives. Bioorganic Medicinal Chemistry Letters. 25(13): 2664-2667. (DOI: 10.1016/j. bmcl.2015.04.079).

16. B. S. Holla, B. Veerendra, M. K. Shivananda, and B. Poojary, Synthesis characterization and anticancer activity studies on some Mannich bases derived from 1,2,4-triazoles. European Journal of Medicinal Chemistry, 2003, 38(7-8), 759-767. (DOI: 10.1016/S0223-5234(03)00128-4).

17. Y. A. Al-Soud, I. A. Al-Masoudi, B. Saeed, U. Beifuss, and N. A. Al-Masoudi, Synthesis of new $1 H$-1,2,4-triazolylcoumarins and their antitumor and anti-HIV activities. Chemistry of Heterocyclic Compounds, 2006, 42(5), 583-590. (DOI: 10.1007/ s10593-006-0130-2)

18.B. A. Baviskar, S. S. Khadabadi, S. L. Deore, and M. R. Shiradkar, Synthesis of clubbed triazolylindeno [1,2-C] isoquinolines as a novel anticancer agent, Der Pharmacia Sinica, 2012, 3(1), 24-30.

19. S. Pokuri, R. K. Singla, V. G. Bhat and G. G. Shenoy, Insights on the antioxidant potential of 1,2,4-triazoles: synthesis, screening \& QSAR studies, Current Drug Metabolism, 2014, 14(4), 389-397. (DOI: 10.2174/13892002156661409081 01958).

20.G. D. Kini, E. M. Henry, R. K. Robins, S. B. Larson, J. J. Marr, R. L. Berens, C. J. Bacchi, H. C. Nathan and J. S. Keithly, Synthesis, structure, and antiparasitic activity of sulfamoyl derivatives of ribavirin, Journal of Medicinal Chemistry, 1990, 33(1), 44-48. (DOI: 10.1021/jm00163a008).

21.H. Gobel, Efficacy and tolerability of rizatriptan $10 \mathrm{mg}$ compared with sumatriptan $100 \mathrm{mg}$ : an evidence-based analysis, Expert Review of Neurotherapeutics, 2010, 10(4), 499-506. (DOI: 10.1586/ern.10.24).

22. Y. K. Lee, and A. W. Fothergill, In vitro antifungal activities of amphotericin B, fluconazole, Itraconazole, Terbinafine, Caspofungin, Voriconazole, and Posaconazole against 30 clinical isolates of Cryptococcus neoformans var. neoformancs, Mycobiology, 2003, 31(2), 95-98. (DOI: 10.4489/MYCO.2003.31.2.095).

23. C. Mauro and P. Sperlongano, Controlled clinical evaluation of 2 hyptonic triazole benzpdiazpines, estazolam and triazolam, used the night before surgical interventions, Minerva Medica, 1987,
78(18), 1381-1384.

24. J. C. Verster and E. R. Volkerts, Clinical pharmacology, clinical efficacy, and behavioral toxicity of Alprazolam: A review of the literature, CNS Drug Reviews, 2004, 10(1), 45-47. (DOI: 10.1111/j.1527-3458.2004.tb00003.x).

25.P. E. Goss and K. Strasser-Weippl, Aromatase inhibitors for chemoprevention, Best Practice \& Research Clinical Endocrinology \& Metabolism, 2004, 18(1), 113-130. (DOI: 10.1016/s1521690x(03)00070-8).

26. R. J. Santen, H. Brodie, E. R. Simpson, P. K. Siiteri and A. Brodie, History of aromatase: Saga of an important biological mediator and therapeutic target, 2009, 30(4), 343-375. (DOI: 10.1210/ er.2008-0016).

27. T. Plech, J. J. Luszczki, M. Wujec, J. Flieger and M. Pizon, Synthesis, characterization and preliminary anticonvulsant evaluation of some 4-alkyl-1,2,4-triazoles. European Journal of Medicinal Chemistry, 2013 60, 208-215. (DOI: 10.1016/j.ejmech.2012.11.026).

28. I. Küçükgüzel, E. Tatar, G. Küçükgüzel, S. Rollas, and E. De Clercq, Synthesis of some novel thiourea deriatives obtained from 5-[(4-aminophenoxy) methyl]-4-alkyl/aryl-2,4-dihydro-3 $H$-1,2,4triazole-3-thiones and evaluation as antiviral/ anti-HIV and anti-tuberculosis agents. European Journal of Medicinal Chemistry, 2008, 43, 381392. (DOI: 10.1016/j.ejmech.2007.04.010).

29. G. Charitos, D. T. Trafalis, P. Dalezis, C. Potamitis, V. Sarli, P. Zoumpoulakis, C. Camoutsis, Synthesis and anticancer activity of novel 3,6-disubstituted 1,2,4-triazolo-[3,4-b]-1,3,4-thiadiazole derivatives, Arabian Journal of Chemistry, 12(8), 4784-4794. (DOI: 10.1016/j.arabjc.2016.09.015).

30. M. Tramontini, and L. Angiolini, Mannich bases Chemsitry and Uses, $1^{\text {st }}$ edition, CRC Press, USA, 1994, 1, 2-2. (ISBN 0-8493-4430-1).

31. S. Joshi, N. Khosla and P. Tiwari, In vitro study of some medicinally important Mannich bases derived from anti-tubercular agent, Bioorganic and Medicinal Chemistry, 2004, 12(3), 571-576. (DOI: 10.1016/j.bmc.2003.11.001).

32.D. Sriram, D. Banerjee and P. Yogeeswari, Efavirenz Mannich bases: Synthesis, anti-HIV and antitubercular activities. Journal of Enzyme Inhibition and Medicinal Chemistry, 2009, 24(1), 1-5. (DOI: 10.1080/14756360701404159).

33. F. Lopes, R. Capela, J. O. Goncaves, P. N. Horton, M. B. Hursthouse, J. Iley, C. M. Casimiro, J. Bom, and R. Moreira, Amidomethylation of amodiaquine: antimalarial $N$-Mannich base derivatives, Tetrahedron Letters, 2004, 45(41), 
7663-7666. (DOI: 10.1016/j.tetlet.2004.08.093).

34.M. G. Ferlin, G. Chiarelotto, F. Antonucci, L. Caparrotta, and G. Froldi, Mannich bases of $3 H$-pyrrolo[3,2-f] quinolone having vasorelaxing activities, European Journal of Medicinal Chemistry, 2002, 37(5), 427-434. (DOI: 10.1016/ S0223-5234(02)01355-7).

35. Y. Ivanova, G. Momekov, O. Petrov, M. Karaivanova, and V. Kalcheva, Cytotoxic Mannich bases of 6-(3-aryl-2-propenoyl)-2(3H)benzoxazolone. European Journal of Medicinal Chemistry, 2007, 42(11-12), 1382-1387. (DOI: 10.1016/j.ejmech.2007.02.019).

36. M. Köksal, N. Gökhan, E. Küpeli, E. Yesilada, and H. Erdogan, Analgesic and antiinflammatory activities of some new Mannich bases of 5-nitro2-benzoxazolinones. Archives of Pharmacal Research, 30(4), 419-424. (DOI: 10.1007/ bf02980214).

37.M. Ashok, B. S. Holla, and B. Poojary, Convenient one pot synthesis and antimicrobial evaluation of some new Mannich bases carrying 4-methylthiobenzyl moiety, European Journal of Medicinal Chemistry, 2007, 42(8) 1095-1101. (DOI: 10.1016/j.ejmech.2007.01.015).

38. S. N. Pandeya, D. Sriram, G. Nath, and E. De Clercq, Synthesis, antibacterial, antifungal and anti-HIV activities of norfloxacin Mannich bases, European Journal of Medicinal Chemistry, 2000, 35(2), 249-255. (DOI: 10.1016/s02235234(00)00125-2).

39. S. C. Vashishtha, G. A. Zello, K. H. Nienaber, J. Balzarini, E. DeClercq, J.P. Stables, J. R. Dimmock, Cytotoxic and anticonvulsant aryloxyaryl Mannich bases and related compounds. European Journal of Medicinal Chemistry, 2004, 39(1), 2735. (DOI: 10.1016/j.ejmech.2003.09.011).

40.E. Bennet-Jenkins, and C. Bryant, Novel sources of anthelmintics, International Journal for Parasitology, 2004, 26(8-9), 937-947. (DOI: 10.1016/S0020-7519(96)80068-3).

41.W. Malinka, P. Swiatek, B. Filipek, J. Sapa, A. Jezierska, and A. Koll, Synthesis, analgesic activity and computational study of new isothiazolopyridines of Mannich base type, Il Farmaco, 2005, 60 (11-12), 961-968. (DOI: 10.1016/j.farmac.2005.08.005).

42. M. K. Scott, G. E. Martin, D. L. DiStefano, C. L. Fedde, M. J. Kukla, D. L. Barrett, W. J. Baldy, R. J. Eldin Jr., J. M. Kesslick, J. R. Mathiasen, R. P. Shank, and J. L. Vaugt, Pyrrole Mannich bases as potential antipsychotic agents, Journal of Medicinal Chemistry, 1992, 35(3), 552-558. (DOI: 10.1021/jm00081a018).
43. M. L. Edwards, H. W. Ritter, D. M. Stemerick, and K. T. Stewart, Mannich bases of 4-phenyl-3-buten2-one: A new class of antiherpes agent, Journal of Medicinal Chemistry, 1983, 26(3), 431-436. (DOI: $10.1021 / \mathrm{jm} 00357 \mathrm{a} 020)$.

44.F. P. Otto, Liquid hydrocarbon fuels containing high molecular weight Mannich bases, U. S. Patent, US3649229, March 14, 1972.

45. J-J. Lin, S-F. Lin, T-T. Kuo, F-C. Chang, and F-P. Tseng, Synthesis and epoxy curing of Mannich bases derived from bisphenol $\mathrm{A}$ and poly(oxyalkylene)diamine, Journal of Applied Polymer Science, 2000, 78(3), 615-623. (DOI: 10.1002/1097-4628(20001017)78:3<615::AIDAPP170>3.0.CO;2-N).

46. V. M. Balakin, S. M. Balakin, and A. G. Tesler, A study of reactions of polymers containing primary or secondary amino groups in their structure. Deposited Doc., 1977, VINITI, 1359-1377. (Chem. Abstr. 90, 187670).

47. R. E. Karll and R. J. Lee, Process and compositions, US Patent 4384138, May 17, 1983.

48.C. Mannich and W. Krosche, Ueber ein kondensationsprodukt aus formaldehyd, ammoniak und antipyrin, Archiv der Pharmazie, 1912, 250(1), 647-667. (DOI: https://doi. org/10.1002/ardp.19122500151).

49. C. Zhang, A. Cheng, J. Tang, G. Yang and H. Xi, Synthesis and biological activity of novel Mannich bases of 5-alkyl-1,2,4-triazole, Chinese Journal of Applied Chemistry, 2016, 33(5), 554-564. (DOI: 10.11944/j.issn.1000-0518.2016.05.150267).

50. B. S. Furniss, A. J. Hannaford, P. W. G. Smith, and A. R. Tatchell, Vogel's Text Book of Practical Organic Chemistry, 5 Ed. Longman Scientific and Technical, copublished in the United States with John Wiley and Sons Inc., New York, USA, 1991; pp 1077 \& 1269.

51. N. Ergenc, N. Ulusoy, G. Capan, G. O. Sanis and M. Kiraz, Synthesis and antimicrobial properties of new 4-(alkylidene/arylidene)-amino-5-(2furanyl)-2,4-dihydro-3 $\mathrm{H}$-1,2,4-triazole-3-thiones and 6-aryl-3-(2-furanyl)-7H-1,2,4-triazole[3,4-b] [1,3,4] thiadiazines, Archiv der Pharmazie, 1996, 329(8-9), 427-430. (DOI: 10.1002/ ardp.19963290811).

52. J. R. Reid and N. D. Heindel, Improved synthesis of 5-substituted-4-amino-3-mercapto-(4H)-1,2,4triazoles, Journal of Heterocyclic Chemistry, 1976, 13, 925-926. (DOI: 10.1002/jhet.5570130450B.

53. D. Sunil, A. M. Isloor, P. Shetty, B. Chandrakantha and K. Satymoorthy, Synthesis, characterization and in vitro cytotoxic properties of some new Schiff and Mannich bases in Hep G2 cells, 
Medicinal Chemistry Research, 2011, 20, 10241032. (DOI: 10.1007/s0004-010-9433-z).

54.C. Perez, M. Paul and P. Bazerque, Antibiotic assay by agar well diffusion method, Acta Biologiae et Medicinae Experimentalis, 1990, 15, 113-115.

55.K. Devkota, G. Pathak and B. Shakya, Synthesis and evaluation of Schiff bases of 4-amino-5(chlorine substituted phenyl)-4H-1,2,4-triazole-3thione as antimicrobial agents, Journal of Nepal Chemical Society, 2020, 41(1) 26-35. (DOI: 10.3126/jncs.v41i1.30373).

56. O. D. Cretu, S. F. Barbuceanu, G. Saramet and C. Draghici, Synthesis and characterization of some 1,2,4-triazole-3-thiones obtained from intramolecular cyclization of new 1 -(4-(4-X-phenylsulfonyl)benzoyl)-4-(4iodophenyl)-3-thiosemicarbazides, Journal of Serbian Chemical Society, 2010, 75(11), 14631471. (DOI: 10.2298/JSC091221122C).

57. M. Hanif and Z. Chohan, Synthesis, spectral characterization and biological studies of transition metal(II) complexes with triazole Schiff bases, Applied Organometallic Chemistry, 2013, 27, 36-44. (DOI: 10.1002/aoc.2936).

58. K. Zamani, K. Faghihi, T. Tofighi and M. R. Shariatzadeh, Synthesis and antimicrobial activity of some pyridyl and naphthyl substituted 1,2,4-Triazole and 1,3,4-thiadiazole derivatives, Turkish Journal of Chemistry, 2004, 28, 95-100.
59. S. Baluja, S. Chanda, R. Chabhadiya, N. Kachhadia, R. Nair and A. Solanki, A facile synthesis and the antimicrobial activity of some 4-aryltriazoles, Journal of the Serbian Chemical Society, 2007, 72(6), 539-544. (DOI: 10.2298/ JSC0706539B).

60. R. M. Silverstein and F. C. Webster, Spectrometric Identification of Organic Compounds, 6th Ed., John Wiley, USA, 2002, 3, 106.

61. M. A. Ali, A. H. Mirza, R. J. Butcher and K. A. Crouse, The preparation, characterization and biological activity of palladium(II) and platinum(II) complexes of tridentate NNS ligands derived from S-methyl- and S-benzyldithiocarbazates and the $\mathrm{X}$-ray crystal structure of the $[\mathrm{Pd}(\mathrm{mpasme}) \mathrm{Cl}]$ complex, Transition Metal Chemistry, 2006, 31, 79-87. (DOI: 10.1007/s11243-005-6305-3).

62. B. Wang, Y. Shi, Y. Zhan, L. Zhang, Y. Zhang, L. Wang, X. Zhang, L. Yonghong, L, Zhengming and L. Baoju, Synthesis and biological activity of novel furan/thiophene and piperazine-containing (bis) 1,2,4-triazole Mannich bases, Chinese Journal of Chemistry, 2015, 33(10), 1124-1134. (DOI: 10.1002/cjoc.201500436).

63. Y. M. Issa, H. B. Hassib and H. E. Abdelaal, ${ }^{1} \mathrm{H}$ NMR, ${ }^{13} \mathrm{C}$ NMR and mass spectral studies of some Schiff bases derived from 3-amino-1,2,4triazole, Spectrochimica Acta Part A: Molecular and Biomolecular Spectroscopy, 2009, 74(4), 902910. (DOI: 10.1016/j.saa.2009.08.042). 